\title{
Renal Risk of Contrast-Enhanced Imaging - Is It a Myth? The Latest Opinions of the Guidelines
}

\author{
Daniela RADULESCU ${ }^{1,2}$, Cristiana DAVID ${ }^{1,2}$, Ileana Adela VACAROIU1,2
}

\begin{abstract}
Over the last decade, several divergent views have been expressed regarding the effect that iodinated contrast agents may have on renal function. Evidence-based medicine often requires the recommendation of high-performance contrast-enhanced imaging exams for precise positive diagnosis. The fear of intravenous contrast use in patients with elevated serum creatinine seems to become an old dogma, outdated by the benefits of the procedures. Patients with glomerular filtration rate below $30 \mathrm{~mL} / \mathrm{min} / 1.73 \mathrm{~m}^{2}$ can be protected by peri-procedural hydration and withdrawal of other nephrotoxics. Whatever the degree of risk, current guidelines recommend contrast-enhanced investigations in any situations where the advantages for the diagnosis are certain.
\end{abstract}

Keywords: contrast agent, nephrotoxic, contrast-induced AKI, risk, prophylaxis, hydration.

\section{Rezumat}

În ultimii ani au fost avansate numeroase opinii divergente cu privire la efectul nefrotoxic al substanțelor de contrast. Medicina bazată pe dovezi impune frecvent prescrierea de investigații imagistice performante, punându-ne în fața unei dileme: este justificată teama de prescriere a mediilor de contrast la pacientul renal cronic, sau continuăm să perpetuăm o dogmă veche fără fundament științific solid? Studiile recente pe care se bazează recomandările ghidurilor moderne arată că nefropatia de contrast este o excepție la valori ale ratei filtrării glomerulare de peste 30 $\mathrm{ml} / \mathrm{min} / 1,73 \mathrm{~m}^{2}$, iar sub acest nivel poate fi prevenită cu hidratare corectă peri-procedurală și retragerea altor nefrotoxice. Un raport pozitiv beneficii/riscuri este cheia deciziei medicale în fiecare situație care impune investigație cu contrast.

Cuvinte cheie: substanță de contrast, nefropatie de contrast, risc, profilaxie, hidratare.

Over the last decade, several divergent views have been expressed regarding the effect that iodinated contrast agents may have on renal function. From the classic contraindication of intravenous contrast use in patients with elevated serum creatinine, to the more nuanced indication of proper hydration and after-investigation monitoring of the renal patient to whom we decide to administer a contrast media, in the recent years it has been reached to the denial of the nephrotoxic risk of these investigations.

A precise positive diagnosis is crucial in our days, and this often requires the prescription of high-performance imaging. On the other hand, the modern evidence-based medicine penalizes us when it detects iatrogenic adverse events, complications which could have been avoided by better medical decisions. There-
' Clinical Department No. 3, „Carol Davila" University of Medicine and Pharmacy, Bucharest, Romania

2 Department of Nephrology and Dialysis, "Sfantul Ioan"

Emergency Clinical Hospital, Bucharest, Romania
Corresponding author.

Daniela RADULESCU, Department of Nephrology and Dialysis,

„Sfantul Ioan" Emergency Clinical Hospital, Bucharest, Romania.

"E-mail: danielaradulescu64@yahoo.com 
fore, is it the risk of acute kidney injury enough to justify the fear for prescribing imaging investigations, or is time to reconsider the old dogma? In order to decide where we stand at the moment and what attitude to follow in our current practice, it is imperative to study the most recent opinions of the guidelines and the results of the latest studies on the subject of renal injuries due to contrast media.

It has been documented that iodinated contrast agents administered intravenously can act in the renal tubules by direct cell toxicity and by the release of vasoactive mediators, inducing medullary vasoconstriction that causes hypoxia in tubular cells ${ }^{1-4}$. Several studies conclude that they are also involved in cytotoxicity with the consequences of an imbalance in the local level of vasodilators, activation of oxidative stress, increased viscosity in the peritubular capillaries and functional deficit of mitochondria in the tubular cells ${ }^{5-7}$.

Due to these tubular processes, contrast-induced acute kidney injury (AKI) develops, diagnosed as an increase in serum creatinine of more than $0.5 \mathrm{mg} / \mathrm{dl}$ or more than $25 \%$ of baseline within 2-5 days after administration of the contrast media ${ }^{8-10}$.

There are specialists that consider the contrast-induced AKI (CI-AKI) as a serious condition, one of the most common cause of AKI and an important cause of in-hospital morbidity and mortality, underlying its potential to develop nonreversible renal damage and chronic kidney disease ${ }^{11-14}$. In consensus with these opinions, the KDIGO (Kidney Disease Improving Global Outcomes) 2012 guidelines rely on studies performed in that period and concludes that contrast-induced AKI incidence is extremely variable but it can reach $25 \%$ of the investigated patients in some facilities; therefore, for safety, it recommends prophylactic actions in all patients with glomerular filtration rate (GFR) below $60 \mathrm{~mL} / \mathrm{min} / 1.73 \mathrm{~m}^{2}$ to whom we intend to administer intravascular contrast (intravenous or intra-arterial) $)^{8,15}$. The European Society of Urogenital Radiology, based on studies by Choyke and colleagues, indicates to assess the risk of CI-AKI by determining the presence of proteinuria, an investigation that is easier to perform than creatinine and GFR calculation, requiring only urinary strips screening; the guide indicates pre- and post- contrast hydration prophylaxis and serum creatinine monitoring at 2-5 days after contrast only in patients with detected proteinuria, considered to have pre-existing renal impairment ${ }^{10,16}$.

Classic cardiology guidelines contain warnings of the risk that coronary angiography poses to the patient with any kind of renal function impairment, even thou- gh that modification is not clinically manifest; a percentage of $5-10 \%$ is stated for patients who may develop CI-AKI after intravascular injected contrast during the procedure $^{17,18}$. Prophylaxis actions are indicated in all patients with GFR below $60 \mathrm{~mL} / \mathrm{min} / 1.73 \mathrm{~m}^{2}$, namely the use of low contrast doses, low-osmolarity agents, the avoidance of other nephrotoxic drugs and ensuring an appropriate hydration during the procedure ${ }^{17,18}$.

The last five years bring a change of opinion. Unlike the recommendations of classical guidelines, the latest statement from the American Society of Radiology is based on the results of recent clinical trials and considers that the effect of iodinated contrast media on renal tubules has been overestimated ${ }^{19}$. In support of this assertion, the experts point out the differences stated by KDIGO between 'contrast-associated AKI' (CA$\mathrm{AKI})$ and 'contrast-induced AKI' (CI-AKI), meaning that different kind of subsequent causes of AKI were blamed on the contrast media ${ }^{8,19}$. We should diagnose CI-AKI only when a direct causality relation can be established between the contrast administration and the renal damage. This separates the situations in which AKI develops in patients with multiple renal risk factors and who have undergone an imaging investigation in the last week, versus patients who develop AKI immediately after performing the contrast imaging and in whom the causal relationship between the two is certain. According to this guideline, CI-AKI is a rare entity, being highlighted in very few cases of renal insufficiency developed after an imaging investigation/ procedure. The combination of other nephrotoxic drugs and dehydration are factors that far exceed the risk potential of iodinated contrast media. For these reasons, pre-contrast hydration and withdrawal of nephrotoxic medication would almost completely cover the risk of contrast media nephrotoxicity. Therefore, the guideline imposes these two precise actions only for patients with GFR value situated below $30 \mathrm{~mL} / \mathrm{min} / 1.73 \mathrm{~m}^{2}$, considering that above this rate of glomerular filtration there is no risk for the performance of contrast imaging $^{19}$.

Consistent with this new perspective, the Medscape platform states in February 2020 that pre-contrast hydration would no longer be considered necessary before contrast enhanced computed tomography examination in renal patients with GFR over $30 \mathrm{~mL} / \mathrm{min} / 1.73 \mathrm{~m}^{2}{ }^{20}$. This time, the claim is based on the results of a recent Dutch study, Kompas, which demonstrated the same creatinine values 2-5 days after iv contrast administration in patients with chronic kidney disease (CKD) stage 3 (GFR $30-60 \mathrm{~mL} / \mathrm{min} / 1.73 \mathrm{~m}^{2}$ ) included in the 
Renal Risk of Contrast-Enhanced Imaging - Is It a Myth? The Latest Opinions of the Guidelines

Table 1. CI-AKI prophylaxis methods and pros / cons studies ${ }^{11}$

\begin{tabular}{|c|c|c|}
\hline Prophylaxis strategies & „Pros" studies & "Cons" studies \\
\hline $\begin{array}{l}\text { Hidration with } 0.9 \% \text { saline } \\
1 \mathrm{ml} / \mathrm{kg} / \mathrm{h}, 4-6 \mathrm{~h} \text { pre and post }\end{array}$ & $\begin{array}{c}\text { Mueller } 2002^{27} \text {, Trivedi200328, } \\
\text { Brar } 2014^{29} \text {, Luo } 2014^{30}\end{array}$ & Timal $2020^{21}$, Nijssen $2019^{22}$ \\
\hline Sodium Bicarbonate alone or added in $0.9 \%$ saline solution & $\begin{array}{c}\text { Van der Molen } 2018^{24} \\
\text { Merten } 2004^{31}, \text { Hoste } 2010^{32}\end{array}$ & Brar $2008^{33}$, Solomon $2015^{34}$ \\
\hline $\begin{array}{l}\mathrm{N} \text {-acetylcysteine } \\
600 \mathrm{mg} \text { bid }\end{array}$ & KDOGO $2012^{8}$, Lameire $2006^{35}$ & $\begin{array}{l}\text { ACT investigators } 2011^{36}, \\
\text { Zagler } 2006^{37}\end{array}$ \\
\hline Prophylactic hemodialysis & - & Ozkok $2017^{11}$, Cruz $2012^{38}$ \\
\hline $\begin{array}{l}\text { Stop nephrotoxic medication } \\
\text { ACEI/ARB, metformin }\end{array}$ & Rim $2012^{39}$, Thomsen $1999^{40}$ & $\begin{array}{c}\text { Rosenstock } 2008^{41} \\
\text { Owen } 2014^{42}\end{array}$ \\
\hline
\end{tabular}

trial $^{21}$. The same conclusion results from investigations in the AMACING study performed by Maastricht University Medical Centre and published in $2017^{22}$.

Therefore, current opinion, accepted by all guidelines, is to apply pre-procedural prophylactic measures only to stage 4 or $5 \mathrm{CKD}$ patients programmed to receive intra-vascular contrast media. These measures, available in any medical facility, include: the use of substances with the lowest possible osmolarity; isotonic saline hydration before and after contrast (use of sodium bicarbonate only in the presence of metabolic acidosis), with caution in heart failure cases; withdrawal / avoidance of other nephrotoxics on the day/around of investigation (eg. angiotensin converting enzyme inhibitors, metformin, nonsteroidal anti-inflammatory drugs, aminoglycosides); avoidance of early repetition of contrast administration. Other prophylaxy methods have not proven effective, although several of them are still used in daily practice (Table 1$)^{11,23,24}$.

The prognosis is good in the majority of cases, with renal function normalizing in 1-3 weeks ${ }^{17,26,43}$. Prophylactic hemodialysis has no benefits in CI-AKI; in confirmed AKI, initiating of dialysis follows the same indications as in other types of AKI, with the peculiarity

\section{References}

1. Heyman SN, Brezis M, Epstein FH, Spokes K, Silva P, Rosen S. Early renal medullary hypoxic injury from radiocontrast and indomethacin.Kidney Int. 1991 Oct; 40(4):632-42.

2. Sendeski M, Patzak A, Pallone TL, Cao C, Persson AE, Persson PB. Iodixanol, constriction of medullary descending vasa recta, and risk for contrast medium-induced nephropathy.Radiology. 2009 Jun; 251(3):697-704.

3. Nazıroğlu $M$, Yoldaş $N$, Uzgur EN, Kayan M Role of contrast media on oxidative stress, $\mathrm{Ca}(2+)$ signaling and apoptosis in kidney.J Membr Biol. 2013 Feb; 246(2):91-100.

4. Peer A, Averbukh Z, Berman S, Modai D, Averbukh M, Weissgarten $\mathrm{J}$. Contrast media augmented apoptosis of cultured renal mesangial, tubular, epithelial, endothelial, and hepatic cells.Invest Radiol. 2003 Mar; 38(3): 177-82

5. Liu ZZ, Schmerbach K, Lu Y, Perlewitz A, Nikitina T, Cantow K, Seeliger E, Persson PB, Patzak A, Liu R, Sendeski MM. lodinated of substantial benefit in early initiation in patients with clinically manifest hyperhydration. ${ }^{8,25,44}$.

\section{CONCLUSIONS}

Acute renal injury is a severe condition with significant lethal potential, but its occurrence due to the administration of iodinated contrast agents is an exception in patients without renal impairment and is minimal in early chronic kidney disease. Patients with glomerular filtration rate below $30 \mathrm{~mL} / \mathrm{min} / 1.73 \mathrm{~m}^{2}$ can be protected by pre-contrast hydration and withdrawal of other nephrotoxics. Whatever the degree of risk, current guidelines recommend the administration of contrast in any situations where the benefits for the diagnosis or for the treatment are certain.

Compliance with ethics requirements: The authors declare no conflict of interest regarding this article. The authors declare that all the procedures and experiments of this study respect the ethical standards in the Helsinki Declaration of 1975, as revised in 2008(5), as well as the national law. Informed consent was obtained from all the patients included in the study.

contrast media cause direct tubular cell damage, leading to oxidative stress, low nitric oxide, and impairment of tubuloglomerular feedback.Am J Physiol Renal Physiol. 2014 Apr 15; 306(8) F864-72.

6. Heyman SN, Rosen S, Khamaisi M, Idée JM, Rosenberger C. Reactive oxygen species and the pathogenesis of radiocontrastinduced nephropathy. Invest Radiol. 2010 Apr; 45(4):188-95.

7. Hardiek K, Katholi RE, Ramkumar V, Deitrick C. Proximal tubule cell response to radiographic contrast media. Am J Physiol Renal Physiol. 2001;280:F61-F70

8. Kidney Disease: Improving Global Outcomes (KDIGO) AKI Work Group. KDIGO clinical practice guideline for acute kidney injury. Kidney Inter Suppl 2012;2:1-138.

9. Harjai KJ, Raizada A, Shenoy C,et al.A comparison of contemporary definitions of contrast nephropathy in patients undergoing percutaneous coronary intervention and a proposal for a no- 
vel nephropathy grading system. Am J Cardiol 2008;101:812819.386.

10. Thomsen HS, Morcos SK. Contrast media and the kidney: European Society of Urogenital Radiology (ESUR) guidelines. Br J Radiol 2003;76:513-518.

11. Ozkok S, Ozkok A. Contrast-induced acute kidney injury: A review of practical points. World J Nephrol. 2017;6(3):86 99.

12. Rudnick $M$, Feldman $H$. Contrast-induced nephropathy: what are the true clinical consequences? Clin J Am Soc Nephrol. 2008 Jan; 3(1):263-72

13. Amin A.P., Salisbury A.C., McCullough P.A., et al. Trends in the incidence of acute kidney injury in patients hospitalized with acute myocardial infarction. Arch Intern Med 2012;172:246-253.

14. Tsai T.T., Patel U.D., Chang T.I., et al. Contemporary incidence, predictors, and outcomes of acute kidney injury in patients undergoing percutaneous coronary interventions: insights from the NCDR Cath-PCI Registry. J Am Coll Cardiol Intv 2014;7:1-9.

15. Lameire $N$, Adam $A$, Becker $C R$,et al.Baseline renal function screening.Am J Cardiol2006;98:21K-26K.

16. Choyke PL, Cady J, DePollar SL,et al.Determination of serum creatinineprior to iodinated contrast media: is it necessary in all patients?Tech Urol1998;4:65-69.

17. McCullough PA, Choi JP, Feghali GA, et al. Contrast-Induced Acute Kidney Injury. J Am Coll Cardiol. 2016 Sep, 68 (13) 14651473

18. Windecker S,Kolh P, Alfonso F.et al. 2014 ESC/EACTS guidelines on myocardial revascularization: The Task Force on Myocardial Revascularization of the European Society of Cardiology (ESC) and the European Association for Cardio-Thoracic Surgery (EACTS).Eur Heart J. 2014; 35: 2541-2619

19. Davenport MS et al. Use of intravenous iodinated contrast media in patients with kidney disease: Consensus statements from thirmații, se American College of Radiology and the National Kidney Foundation. Radiology 2020 Mar; 294:660

20. Hydration Unnecessary to Prevent Contrast-Enhanced Nephropathy - Medscape - Feb 19, 2020. https://www.medscape. com/viewarticle/925411 accesat mai 2020

21. Timal RJ, Kooiman J, Sijpkens YWJ, et al. Effect of No Prehydration vs Sodium Bicarbonate Prehydration Prior to Contrast-Enhanced Computed Tomography in the Prevention of Postcontrast Acute Kidney Injury in Adults With Chronic Kidney Disease: The Kompas Randomized Clinical Trial. JAMA Intern Med. 2020;180(4):533-541

22. Nijssen, E.C., Nelemans, P.J., Rennenberg, R.J. et al. To hydrate or not to hydrate? Lessons learned from the AMACING trial. Chin J Acad Radiol 1, 2-5 (2019)

23. NICE Surveillance report (exceptional review) 2017-Acute kidney injury: prevention, detection and management (2013) NICE guideline CG169 https://www.nice.org.uk/guidance/cg169/ resources/surveillance-report-exceptional-review-2017-acute-kidney-injury-prevention-detection-and-management2013-nice-guideline-cg169-4666260925/chapter/Surveillance-decision?tab=evidenceaccesat mai2020

24. Van der Molen AJ, Reimer P, Dekers IA, et al. Post-contrast acute kidney injury: Recommendations for updated ESUR Contrast Medium Safety Committee guidelines: Part 2: risk stratification, role of hydration and other prophylactic measures, patients taking metformin and chronic dialysis patients. Eur Radiol. 2018;28(7):2856-69)

25. Wiedemann HP, Wheeler AP, Bernard GR,et al.Comparison of two fluid-management strategies in acute lung injury. $N$ Engl $J$ Med2006;354:2564-2575.550.

26. McCullough PA, Sandberg KR. Epidemiology of contrast-induced nephropathy. Rev Cardiovasc Med 2003;4(Suppl 5):S3-9.

27. Mueller C, Buerkle G, Buettner HJ, Petersen J, Perruchoud AP, Eriksson U, Marsch S, Roskamm H. Prevention of contrast media-associated nephropathy: randomized comparison of 2 hydration regimens in 1620 patients undergoing coronary angioplasty. Arch Intern Med. 2002;162:329-336

28. Trivedi HS, Moore H, Nasr S, Aggarwal K, Agrawal A, Goel P, Hewett $\mathrm{J}$. A randomized prospective trial to assess the role of saline hydration on the development of contrast nephrotoxicity. Nephron Clin Pract. 2003;93:C29-C34.

29. Brar SS, Aharonian V, Mansukhani P, Moore N, Shen AY, Jorgensen M, Dua A, Short L, Kane K. Haemodynamic-guided fluid administration for the prevention of contrast-induced acute kidney injury: the POSEIDON randomised controlled trial. Lancet. 2014;383:1814-1823

30. Luo Y, Wang X, Ye Z, Lai Y, Yao Y, Li J, Liu X. Remedial hydration reduces the incidence of contrast-induced nephropathy and short-term adverse events in patients with ST-segment elevation myocardial infarction: a single-center, randomized trial. Intern Med. 2014; 53(20):2265-72.

31. Merten GJ, Burgess WP, Gray LV, Holleman JH, Roush TS, Kowalchuk GJ, Bersin RM, Van Moore A, Simonton CA, Rittase $R A$, et al. Prevention of contrast-induced nephropathy with sodium bicarbonate: a randomized controlled trial. JAMA. 2004; 291:2328-2334

32. Hoste EA, De Waele JJ, Gevaert SA, Uchino S, Kellum JA. Sodium bicarbonate for prevention of contrast-induced acute kidney injury: a systematic review and meta-analysis. Nephrol Dial Transplant. 2010;25:747-758.

33. Brar SS, Shen AY, Jorgensen MB, Kotlewski A, Aharonian VJ, Desai N, Ree M, Shah Al, Burchette RJ. Sodium bicarbonate vs sodium chloride for the prevention of contrast medium-induced nephropathy in patients undergoing coronary angiography: a randomized trial. JAMA. 2008;300:1038-1046

34. Solomon R, Gordon P, Manoukian SV, Abbott JD, Kereiakes DJ, Jeremias A, Kim M, Dauerman HL; BOSS Trial Investigators. Randomized Trial of Bicarbonate or Saline Study for the Prevention of Contrast-Induced Nephropathy in Patients with CKD. Clin J Am Soc Nephrol. 2015;10:1519-1524.

35. Subramaniam RM, Suarez-Cuervo $C$, Wilson RF, Turban $S$, Zhang A, Sherrod C, Aboagye J, Eng J, Choi MJ, Hutfless S, et al. Effectiveness of Prevention Strategies for Contrast-Induced Nephropathy: A Systematic Review and Meta-analysis. Ann Intern Med. 2016;164:406-416

36. ACT Investigators. Acetylcysteine for prevention of renal outcomes in patients undergoing coronary and peripheral vascular angiography: main results from the randomized Acetylcysteine for Contrast-induced nephropathy Trial (ACT) Circulation. 2011;124:1250-1259.

37. Zagler A, Azadpour M, Mercado C, Hennekens CH. N-acetylcysteine and contrast-induced nephropathy: a meta-analysis of 13 randomized trials. Am Heart J. 2006;151:140-145.

38. Cruz DN, Goh CY, Marenzi G, Corradi V, Ronco C, Perazella MA. Renal replacement therapies for prevention of radiocontrastinduced nephropathy: a systematic review. Am J Med. 2012; 125:66-78.e3.

39. Rim MY, Ro H, Kang WC, Kim AJ, Park H, Chang JH, Lee HH, Chung $W$, Jung JY. The effect of renin-angiotensin-aldosterone system blockade on contrast-induced acute kidney injury: a propensity-matched study. Am J Kidney Dis. 2012;60:576-582.

40. Thomsen HS, Morcos SK. Contrast media and metformin: guidelines to diminish the risk of lactic acidosis in non-insulin-dependent diabetics after administration of contrast media. ESUR Contrast Media Safety Committee. Eur Radiol. 1999:9:738-740.

41. Rosenstock JL, Bruno R, Kim JK, Lubarsky L, Schaller R, Panagopoulos G, DeVita MV, Michelis MF. The effect of withdrawal of ACE inhibitors or angiotensin receptor blockers prior to coronary angiography on the incidence of contrast-induced nephropathy. Int Urol Nephrol. 2008;40:749-755

42. Owen RJ, Hiremath S, Myers A, Fraser-Hill M, Barrett BJ. Canadian Association of Radiologists consensus guidelines for the prevention of contrast-induced nephropathy: update 2012. Can Assoc Radiol J. 2014;65:96-105.

43. Rear R, Bell RM, Hausenloy DJ. Contrast-induced nephropathy following angiography and cardiac interventions. Heart 2016;102:638-648.

44. Mehta RL, McDonald B, Pahl M,et al.Continuous vs. intermittent dialysis for acute renal failure in the ICU: Results from a randomized multicentertrial (abstract).J Am Soc Nephrol1996;7:1456 